\title{
Qualifative Indicators of Company Employee Satisfaction and Their Development in a Particular Period of Time
}

\section{Kvalitativni pokazatelji zadovoljstva uposlenika kompanije i njihova razvoja u promatranome vremenskom razdoblju}

\author{
Preliminary paper • Prethodno priopćenje \\ Received-prispjelo: 24. 6. 2014. \\ Accepted-prihvaćeno: 20. 5. 2015. \\ UDK: $630 * 79 ; 65.015$ \\ doi:10.5552/drind.2015.1420
}

\begin{abstract}
One of the most challenging and, at the same time, the most important skills of experienced managers of these days is the ability to motivate their employees to meet the required job performance in the workplace. At the present time, employee motivation is an atmosphere that meets the interests and needs of employees in the company, stimulates and influences their work performance in order to meet the needs of the organisation as well as their personal needs. This paper deals with the changes in employee motivation in the Slovak furniture manufacturing company and determines which changes in motivation programme should be made in the company in future.
\end{abstract}

Key words: Employee motivation, motivation programme, analysis of motivation, $t$-test, wood industry company.

SAŽETAK • Jedan od najvažnijih izazova i istodobno, jedna od najvažnijih vještina iskusnih menadžera u današnjem trenutku jest sposobnost motiviranja uposlenika za postizanje očekivanih radnih rezultata u poslu koji obavljaju. Danas motivacija uposlenika označava atmosferu koja povezuje interese i potrebe uposlenika u poduzeću, stimulira ih i potječe na učinkovitiji rad kako bi se dosegnule potrebe organizacije u kojoj rade i njihove osobne potrebe. Članak prikazuje promjene u motivaciji uposlenika u poduzécima za proizvodnju namještaja u Slovačkoj i predlaže potrebne promjene u motivacijskim programima unutar poduzeća u budućnosti.

Ključne riječi: motivacija uposlenika, motivacijski program, analiza motivacije, t-test, kompanija drvne industrije

\footnotetext{
${ }^{1}$ Authors are assistant professor and Master of Science at Technical University, Faculty of Wood Science and Technology in Zvolen, Slovakia. ${ }^{2}$ Author is Doctor of Science at University Matej Bel, Faculty of Economics in Banska Bystrica, Slovakia. ${ }^{3}$ Author is professor at University of Zagreb, Faculty of Forestry, Zagreb, Croatia.

${ }^{1}$ Autori su docent i magistar znanosti Tehničkog sveučilišta u Zvolenu, Fakultet drvne tehnologije i znanosti, Slovačka. ${ }^{2}$ Autorica je doktorica znanosti Sveučilišta Matej Bel u Banskoj Bystrici, Ekonomski fakultet, Slovačka. ${ }^{3}$ Autor je profesor Sveučilišta u Zagrebu, Šumarski fakultet, Zagreb, Hrvatska.
} 


\section{INTRODUCTION}

\section{UVOD}

Times, when the main role of a manager or supervisor in the workplace was to assign tasks to employees, are over. Nowadays, employees want to be familiar with the business process and not only to be paid. To provide higher productivity, they are expected to work with responsibility and to contribute to successful achievement of the company goals. For an effective management of human resources in an organisation, it is necessary to establish an adequate organisational structure including the existence of a human resources management department (Stacho et al., 2013). Employees want to discuss their performance results with managers more often and they want to be aware of the importance of their tasks within the company. According to Forsyth (2003), if a manager does not find the right way to motivate staff, workplace absenteeism and fluctuation will rise and taking breaks in an inappropriate way (surfing the Internet, private phone calls), interruption, intrigues, conflicts, dissatisfaction with management will be more obvious. At the same time interest in work, quality and productivity at work, willingness to become responsible, level of submitting proposals, concentration at work, personal participation of an employee and punctuality are declining.

The main condition to motivate staff successfully and at the same time to meet the interests and needs of the employees in the workplace is to make each employee feel valued, empowered and engaged (Jelačić et al. 2012).

This paper presents the analysis of the manufacturing company with respect to the level of motivation.

An essential role of human resource management and its development is to provide positive behaviour of employees and managers. It is a goal-directed behaviour that should enable the organisation to achieve top goals successfully and effectively. The organisation must motivate employees systematically to ensure that the staff work effectively and therefore it must come up with motivational processes (Halík, 2008). Employee motivation can be considered the nature of human resource management. Motivation should be carried out independently of the management system orientation - functional, process or project orientation (Závadský and Droppa, 2013). Goals of the organisation cannot be set and achieved without the appropriate level of employee motivation - their behaviour and productivity. Motivational programmes are an inseparable part of motivation at work (Jelačić et al. 2008, 2012).

Individual as well as team motivational programmes are used in companies as a part of programmes to keep the required level of employee productivity. Motivational programme must be adapted to corporate culture and the company itself. Detailed motivational programmes can very rarely be seen in our companies. It is necessary to change the general approach to the role of employees within the company to carry out this programme and incorporate it in the in- ternal rules of the company. The ideal state would be to develop a tailor-made programme for each employee, but it is very time- and money-consuming (Šatanova et al., 2004). On the other hand, team motivational programme can be ineffective because of differences in motivation of individual employees. In many cases, there are only minor differences within the motivation profile of an employee but they can affect the job performance of an employee essentially. (Hitka and Sirotiaková, 2011).

Further to the above, creativity, motivation and professionalism is the root for improving the effectiveness of job performance of specialists, managers and employees. They present stimulators encouraging employees, and the whole organisation as well, to make processes in the company more dynamic. One of the most challenging and, at the same time, the key managers' ability is to motivate themselves, workmates and also subordinates to achieve higher employee productivity (Galajdová et al., 2007).

The aim of this paper is to identify changes in employee motivation within the company between 2011 and 2013, to determine changes in preferences for motivation factors of employees in a two-year period and, according to these changes, to suggest appropriate solution for the company in the area of motivation at work in the future.

Nowadays, in times of economic crisis, motivational programmes are focused not only on financial incentives but very often also on non-financial incentives, such as -rebuilding teams, providing education and trainings within the company, offering qualifying training courses, language courses, managerial and IT courses, seminars or using different outsourcing market tools (Kampf, 2005; Potkány, 2008). These incentives can be used by the company to cope with the economic crisis. Sport activities and different events organised by the company are other examples of team building. Internal communication within the company is a part of motivation that must not be missed.

Another non-financial method of motivation is to make employees feel appreciated and empowered (Lucas, 2004). Non-monetary incentive preferences should depend on the employee. Motivational programmes and benefits effective for employees are those that can meet their needs for self-actualisation, perhaps even their economic requirements. Tools effective for the employers are those that can help them develop employee potential at low costs.

It is very time- and money-consuming to develop the motivational programme for each company. Deep and goal-directed analysis of the employees is an essential condition for its effectiveness. Based on the present analyses (Vetráková et al., 2007; Hitka et al., 2007; Blašková, 2010; Kropivšek et al., 2011), it can be concluded that the motivational programme in the company can be, based on the average significance of individual motivation factors, unifiable at present. In the future motivation and requirements of employees may change. 


\section{MATERIAL AND METHODS}

\section{MATERIJAL I METODE}

The research was conducted in a wood processing company specialised in furniture and wood product manufacturing. Manufacturing of furniture is carried out in four factories in the town.

A questionnaire, based on asking directed questions, was used to determine the level of motivation and to analyse motivation factors in the selected company. The questionnaire consisted of 30 closed questions (Hitka, 2009). The questionnaire was divided into two parts. Socio-demographic and qualification characteristics of employees were searched in the first part. Basic data about respondents relating to their age, sex, seniority, completed education and job position were obtained in this part. The second part consisted of individual motivation factors through which information was collected about work environment, working conditions, applied appraisal and reward system, about personnel management, health and social care system and system of employee benefits as well as information about employee satisfaction or dissatisfaction, value orientation, relation to work and the company or coworkers' relationship in the company. Motivation factors were placed in alphabetical order so as not to affect the respondents. Respondents evaluated individual motivation factors by one of five levels of significance from a pre-defined 5-point rating scale, where 5 was the most important and 1 was unimportant.

The questionnaires were evaluated by the computer programme STATISTICA 7. Descriptive statistics was used to describe the basic samples. Statistical characteristics, which compressed information about the observed basic samples into smaller number of numerical characteristics and made mutual comparison of samples (2011 and 2013) easy for each motivation factor, were computed. Each motivation factor (quantitative feature) was described summarily by basic characteristics: levels - average $\bar{x}$ and variability - standard deviations $s_{x}$ and coefficients of variation. Subsequently the results were compared by means of inductive statistics.

Besides simple comparison of descriptive characteristic values, considering the selected type of obtained data, testing was carried out of the equality of averages and standard deviations of basic samples. The purpose of testing is to verify statistical significance of differences in averages and standard deviations of individual motivation factors in analysed companies so that the possibility was eliminated that detected differences of descriptive characteristics at the selected level of significance $\alpha=0.05$ were not caused only by mistake made by representative sampling. The null hypothesis vs. the alternative hypothesis was tested; they were as follows:

$$
H_{0}: \mu_{1}=\mu_{2} \quad \text { vs. } \quad H_{1}: \mu_{1} \neq \mu_{2}
$$

$\mathrm{H}_{0}$ : Means of basic samples of examined motivation factors in the observed time are equal.

$\mathrm{H}_{1}$ : Means of basic samples of examined motivation factors in the observed time are not equal.
The Student's $t$ distribution was as follows (if variances are equal):

if $\sigma_{1}^{2}=\sigma_{2}^{2} ; X_{1}$ and $X_{2}$ are independent,

$$
t=\frac{\bar{x}_{1}-\bar{x}_{2}}{\sqrt{\frac{n_{1} \cdot s_{1}^{2}+n_{2} \cdot s_{2}^{2}}{n_{1}+n_{2}-2} \cdot \frac{n_{1}+n_{2}}{n_{1} \cdot n_{2}}}}
$$

and in case that variances are different if $\sigma_{1}^{2} \neq \sigma_{2}^{2} ; X_{1}$ and $X_{2}$ are independent, $t=\frac{\bar{x}_{1}-\bar{x}_{2}}{\sqrt{\frac{s_{1}^{2}}{n_{1}}+\frac{s_{2}^{2}}{n_{2}}}}$

In 2011, the sample of 152 employees was inquired out of a total of 1253 employees. In 2013, 156 employees were inquired out of 1197 employees.

\section{RESULTS AND DISCUSSION 3 REZULTATI I DISKUSIJA}

Current motivational programme of the company uses different financial incentives, education, job rotation, career growth, social policy and employee benefits in the area of human resource management. The aim of the motivational programme is to follow managerial activities in the company and to affect the work behaviour and the attitude of staff to strategic goals of the organisation in order to ensure harmony between the interests of the company and employees and to provide career growth and self-development of employees.

Research of the level of motivation and changes in motivation factors in 2011 and 2013 was carried out among production workers in the company. Databases were formed regarding the basic characteristic - the year, on the basis of acquired data relating to the motivation assessment. Significance was determined of respondent preferences for individual motivation factors depending upon the year. The differences between means of individual motivation factors in the particular years were searched. The aim was to consider whether the differences between averages of individual groups were significant or only random.

There were no significant differences between most of means of individual motivation factors acquired in 2011 and subsequently in 2013. The differences between means are not considered statistically significant. It can be observed that employees of the company are as satisfied with most of the motivation factors as in 2011. Significant differences between means in 2011 and 2013 can be seen only in two factors - job security and social benefits. These factors have $P$-value $<0.05$. It means that the null hypothesis $\mathrm{H}_{0}$ can be partly accepted.

Within our analysis, employees were asked to consider their motivation requirements in the observed period of time despite the economic crisis. The analysis clearly showed that in the company Bučina, Inc. Zvolen (Hitka and Blašková, 2006), no significant changes were observed in motivation in a four-year period.

Based on the findings in the company Slovenské elektrárne Mochovce (Hitka, 2005), it can also be 
Table $1 t$-test results of motivation factor means

Tablica 1. Rezultati $t$-testa prosječnih motivacijskih čimbenika

\begin{tabular}{|l|c|c|}
\hline & t-test / t-test & value / vrijednosti $p$ \\
\hline Atmosphere in the workplace / atmosfera na radnome mjestu & 3.56 & 0.06 \\
\hline Good work team / dobar radni tim & 1.53 & 0.22 \\
\hline Further financial reward / buduće financijske nagrade & 0.04 & 0.84 \\
\hline Workload and type of work / radno opterećenje i vrsta rada & 0.73 & 0.39 \\
\hline Physical effort at work / fizički napor pri radu & 0.56 & 0.45 \\
\hline Job security / sigurnost zaposlenja & 24.53 & 0.00 \\
\hline Information about performance results / informacije o postignutim rezultatima & 0.29 & 0.59 \\
\hline Communication in the workplace / komunikacija na radnome mjestu & 0.93 & 0.34 \\
\hline Name of the company / ime kompanije & 2.62 & 0.11 \\
\hline Opportunity to apply own ability / mogućnost primjene svojih sposobnosti & 1.66 & 0.20 \\
\hline Working time / radno vrijeme & 3.05 & 0.18 \\
\hline Work environment / radno okruženje & 3.05 & 0.28 \\
\hline Moving up corporate ladder / napredovanje u poslu & 0.63 & 0.43 \\
\hline Competences / kompetencije & 0,58 & 0,45 \\
\hline Supervisor's approach / pristup nadređenoga & 1.54 & 0.22 \\
\hline Individual decision making / osobno donošenje odluka & 0.01 & 0.91 \\
\hline Social benefits / socijalne povlastice & 18.16 & 0.00 \\
\hline Fair appraisal system / pravedni sustav nagradivanja & 0.91 & 0.34 \\
\hline Job safety / sigurnost na radu & 1.30 & 0.26 \\
\hline Mental effort / umni napor & 1.07 & 0.30 \\
\hline Education and personal growth / obrazovanje i osobno napredovanje & 0.52 & 0.47 \\
\hline Company relation to the environment / odnos kompanije prema okolišu & 1.62 & 0.20 \\
\hline Free time /slobodno vrijeme & 1.22 & 0.27 \\
\hline Recognition / priznanja & 0.00 & 0.97 \\
\hline Basic salary / osnovna plaća & 1.23 & 0.27 \\
\hline Ne: Signa & \\
\hline
\end{tabular}

Note: Significant motivation factors are in bold / Napomena: Važni su motivacijski čimbenici podebljani.

stated that the fundamental change in motivation in all job positions only occurred after five years. However, this period of time does not have to be the same in other companies. Following our experience, the analysis of motivation should be carried out periodically, once a year. In order to ensure objectivity, the analysis must be carried out systematically and acquired data must be compared with the company achievements and set goals.

\section{CONCLUSION}

\section{ZAKLJUČAK}

The most important requirement for employees' long-term productivity, their willingness and satisfaction is to make employees feel that their work is meaningful, important for the company and also interesting for them, reasonably difficult and with possibilities of personal development. If employees have a clear picture of the situation and opportunities for professional growth and development, if they are satisfied with the rewarding system based on productivity and quality of the work done, long-term productivity and high-quality work can be expected. However, staff must be supported and motivated continuously. Seeing that the development of motivation during a particular period of time is variable, it is necessary to analyse employee motivation continuously and to update motivational programmes of the company according to the needs. Through the analysis of the motivation factors of em- ployees of the company, it was found that almost all motivation factors were the same during the particular period of time. Significant differences were determined only in two factors - job security and social benefits. The ongoing economic crisis, when employees are obliged to keep their job, can be regarded as the cause of both factors. Seeing that companies do not have enough sources for meeting financial requirements of employees, they offer them different social benefits.

The approach chosen to motivate employees within human resource management is the responsibility of company managers. The system that reveals motivation factors in the company must be monitored constantly and evaluated periodically in order to find information about the current state of employee motivation and mainly to predict the development of motivational programmes.

Economic factors should be observed in longer period of time ( $2-6$ years) along with the monitoring of the total economic and social situation of the environment depending upon the development of value orientation of employees that may change during a particular period of time.

\section{Acknowledgement - Zahvala}

This paper represents a partial result of the grant task of the project VEGA 1/0268/13, "Perspective use of facility management for the increased competition of forestry and woodworking companies in the context of outsourcing principles". 


\section{REFERENCES}

\section{LITERATURA}

1. Blašková, M., 2010: Creative Proactive-Concluding Theory of Motivating. Business: Theory and Practice, 11 (1): 39-48. http://dx.doi.org/10.3846/btp.2010.05

2. Forsyth, P., 2003: Jak motivovat lidi. Brno: Computer Press, p. 117.

3. Galajdová, V., et al. 2007: Rozvoj l’udských zdrojov I. Zvolen: Technická univerzita vo Zvolene, p. 227.

4. Halík, J., 2008: Vedenie a riadenie l’udských zdrojov. Praha: Grada Publishing, p. 128.

5. Hitka, M., 2005: Vecná a časová zmena motivácie riadiacich zamestnancov v Slovenských elektrárňach a. s. Mochovce. On-line odborný časopis Manažment v teórii a praxi. EU Bratislava, PHF Košice. 1/2005.

6. Hitka, M.; Blašková, M., 2006: Vývoj motivácie zamestnancov Bučina, a. s. Zvolen. Ekonomika a manažment podniku 1/2006. Výskumný ústav stavebnej informatiky, s.r.o. Košice. pp. 69-82.

7. Hitka, M.; Potkány, M.; Benková, E., 2007: The analysis of motivation factors of wood-working company employees in the field of personnel controlling. Drewno wood, 50 (178), Poznan.

8. Hitka, M., 2009: Model analýzy motivácie zamestnancov výrobných podnikov. Vedecká monografia, ES TU Zvolen. Zvolen, p.150.

9. Hitka, M.; Sirotiaková, M., 2011: Impact of economic crisis on change of motivation of Ekoltech s. r. o. Filakovo employees. Drewno Wood, 54 (185):119-126.

10. Jelačić, D.; Grladinović, T.; Sujová, A.; Galajdová, V., 2008: Motivirajući čimbenici u preradi drva i proizvodnji namještaja, Drvna industrija, 59 (1): 11-21.

11. Jelačić, D.; Moro, M.; Drábek, J.; Sujová, A., 2012: Motivation factors in wood processing plants. Wood Research, 57 (2): 317-330.

12. Kampf, R., 2005: Personal Outsourcing and Controlling. In.: Manažment ludského potenciálu $\mathrm{v}$ podniku, vyd. Žilina: Žilinská univerzita, pp. 111-116.

13. Kropivšek, J.; Jelačić, D.; Grošelj, P., 2011: Motivating employees of slovenian and croatian wood industry com- panies in times of economic downturn. Drvna industrija, 62(2):97-103.http://dx.doi.org/10.5552/drind.2011.1040

14. Lucas, R.; Marinová, M.; Kučerová, J.; Vetrákov Á, M., 2004: HRM practice in emerging economies: A long way to go in the Slovak hotel industry? International Journal of Human Resource Management, 15 (7): 1262-1279. http://dx.doi.org/10.1080/0958519042000238446

15. Potkány, M., 2008: Personnel outsourcing processes. Ekonomie a management, 11 (4): 53-62.

16. Stacho, Z.; Urbancová, H.; Stachová, K., 2013: Organisational arrangement of human resources management in organisations operating in Slovakia and Czech Republic. Acta Universitatis Agriculturae et Silviculturae Mendelianae Brunensis, LXI (7): 2787-2799. http://dx.doi. org/10.11118/actaun201361072787

17. Šatanová, A.; Potkány, M., 2004: Controlling - Modern tool of company control. Ekonomický časopis, 52 (2): 148-165.

18. Vetráková, M.; Hitka, M.; Sedmák, R., 2007: Analýza vývoja motivácie robotníkov v Slovenských elektrárňach a. s. Mochovce z časového a vecného hl'adiska. Ekonomie a management, 1/2007: 84-97.

19. Závadský, J.; Droppa, M., 2013: Organization maturity through consistency of its management system. Advances in Management, XI (12): 1-8.

20. *** StatSoft, Inc. 2004. STATISTICA (data analysis software system), version 7. www.statsoft.com.

\section{Corresponding author:}

Prof. DENIS JELAČIĆ, Ph.D.

University of Zagreb

Faculty of Forestry

Svetosimunska 25

HR-10000 Zagreb, CROATIA

e-mail: djelacic@sumfak.hr 